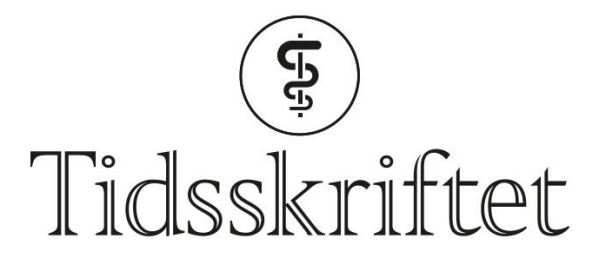

DEN NORSKE LEGEFORENING

\title{
Intrauterin inseminasjon er trygt og effektivt
}

FRA ANDRE TIDSSKRIFTER

ØYVIND STOPLE SIVERTSEN

Tidsskriftet

Inseminasjon i livmor ga flere levendefødte enn forsøk på befruktning på «gamlemåten».

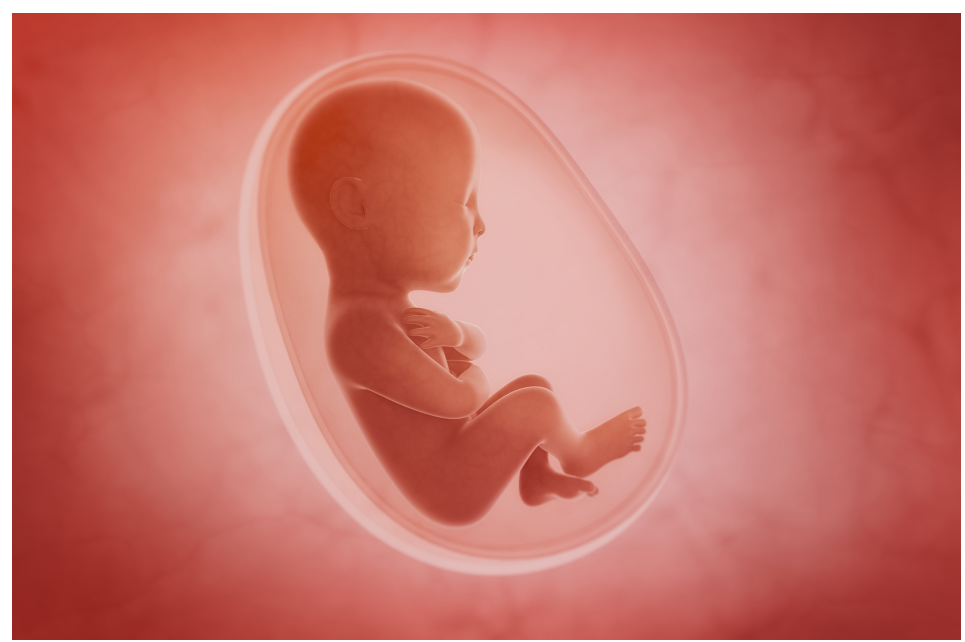

Illustrasjonsfoto: cosmin4ooo/iStock

En ny studie, publisert i The Lancet (1), sammenlignet effekten av inseminasjon av spermier direkte i livmorhulen etter forutgående stimulering av ovariene hos ufrivillig barnløse kvinner med effekten av å oppfordre til samleie rundt den sannsynlige datoen for ovulasjon. Det var rundt 100 kvinner i begge studiegruppene. Av naturlige årsaker var det umulig med blinding av studiedeltagerne.

De som mottok intrauterin inseminasjon, fødte flere barn enn de i kontrollgruppen. Det var 31 levendefødte i denne gruppen, mot ni levendefødte i kontrollgruppen. Behandlingen ga ingen vesentlige bivirkninger.

- Denne studien viser, riktignok i en nokså liten studiepopulasjon, at inseminasjon kommer fordelaktig ut for godt utvalgte personer når man sammenligner med den aller minst invasive formen for fertilitetsbehandling, nemlig veiledning om tidsriktige samleier, sier Hans Ivar Hanevik, som er overlege ved Fertilitetsavdelingen Sør på Sykehuset Telemark og leder i Norsk forening for assistert befruktning.

- Andre nyere studier av fertilitetsbehandling med inseminasjon har gjerne fokusert på fordelene ved slik befruktning inni kroppen sammenlignet med befruktning utenfor 
kroppen, sier han.

- Denne studien bør påvirke revisjonen av bioteknologiloven som nå skjer, der mange $\emptyset n s k e r$ at loven skal tilrettelegge for $\emptyset \mathrm{kt}$ bruk av inseminasjon som behandlingsmåte for ufrivillig barnløse par, sier Hanevik.

LITTERATUR:

1. Farquhar CM, Liu E, Armstrong S et al. Intrauterine insemination with ovarian stimulation versus expectant management for unexplained infertility (TUI): a pragmatic, open-label, randomised, controlled, two-centre trial. Lancet 2018;391: 441 - 50. [PubMed][CrossRef]

Publisert: 12. juni 2018. Tidsskr Nor Legeforen. DOI: 10.4045/tidsskr.18.0300

(C) Tidsskrift for Den norske legeforening 2020. Lastet ned fra tidsskriftet.no 